\title{
The role of drug depots in the informal circulation of medicines in Madagascar
}

\section{Chiarella Mattern}

\section{(2) OpenEdition \\ 1 Journals}

Electronic version

URL: https://journals.openedition.org/rfst/1048

DOI: $10.4000 /$ rfst. 1048

ISSN: 2492-3672

Publisher

Espaces et SOciétés (UMR 6590)

\section{Electronic reference}

Chiarella Mattern, "The role of drug depots in the informal circulation of medicines in Madagascar", Revue francophone sur la santé et les territoires [Online], Healthy circulation: products, knowledge, people on the move, Online since 10 June 2021, connection on 12 June 2021. URL: http:// journals.openedition.org/rfst/1048 ; DOI: https://doi.org/10.4000/rfst.1048

This text was automatically generated on 12 June 2021.

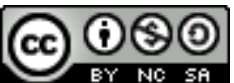

La Revue francophone sur la santé et les territoires est mise à disposition selon les termes de la Licence Creative Commons Attribution - Pas d'Utilisation Commerciale - Partage dans les Mêmes Conditions 4.0 International. 


\title{
The role of drug depots in the informal circulation of medicines in Madagascar
}

\author{
Chiarella Mattern
}

1 The geographical circulation of products used in a therapeutic context at different spatial scales is a phenomenon that has been increasing for several decades with the progression of trade, ease of travel, migration and the spread of biomedicine on a global scale. Health products are now part of economic globalisation and represent a lucrative market that is difficult to quantify due to the formal and informal channels and networks used. The circulation of health products can be analysed from a crossborder point of view but can also be considered at the national level by analysing the organisation of private, public and informal distribution channels; this is the approach adopted in this article. In our work, we have chosen to characterise this market as "informal" in the sense that it involves the sale and purchase of medicines outside the formal framework imposed by the state and by the biomedical health system that prevails in Madagascar. The formulation 'informal market' is generally chosen in anthropology to refer to these practices (Baxerres, 2015).

2 In Madagascar, there are many ways for people to access medicines. The public system supplies medicines to pharmacies in basic health centres and hospitals, while the private system supplies pharmacies in urban areas and medicine depots in rural areas (fivarotam fanafody). Pharmaceutical drugs are also distributed through informal channels in both rural and urban areas. The distribution of formal channels leaves many areas with low drug coverage. In Madagascar, 'the problems [in terms of access to medicines] seemed to be not a general shortage, but a defective organisation at all levels of supply, and unsanctioned trafficking' (Mestre, 2014).

One of the characteristics of the Malagasy pharmaceutical system is the presence of a key player in distribution, making access to medicines possible for populations living in rural areas: drug depots. These were set up in 2011 to compensate for the lack of 
pharmacists on the island and to address the problems of access to essential medicines for the population.

4 This article reports on the role of drug depots in supplying the informal sector. Starting with an analysis of the organisation of drug distribution in Madagascar, we describe the characteristics, operating mechanisms and supply methods of these depots.

This article is based on the results of my thesis, the data of which were collected through three means: semi-structured interviews, direct observations and surveys of informal sales outlets. One hundred semi-structured interviews were conducted between 2013 and 2017 in Madagascar with actors from the different pharmaceutical distribution sectors. Observations of drug dispensing contexts were carried out in Ambohipo during 'floating' moments, while waiting for a salesperson to be available for the interview, or during the interviews, when we were interrupted by a buyer, which happened frequently. Our observations were aimed at understanding the relationship between the sellers, and the relationship between the seller and the user around the acquisition of the drug. Finally, a non-exhaustive survey of informal drug sales outlets was carried out in the eight most frequented and well-known weekly and permanent markets in the capital Antananarivo. In addition, observations and short interviews were conducted with seventy shopkeepers (vegetables, clothes, basic necessities, traditional medicines), street vendors (selling plastic bags, DVDs, foodstuffs, traditional medicines) and grocers in order to identify the different categories of vendors and the routes of informal circulation of medicines in Antananarivo.

\section{Drug deposit at Madagascar.}

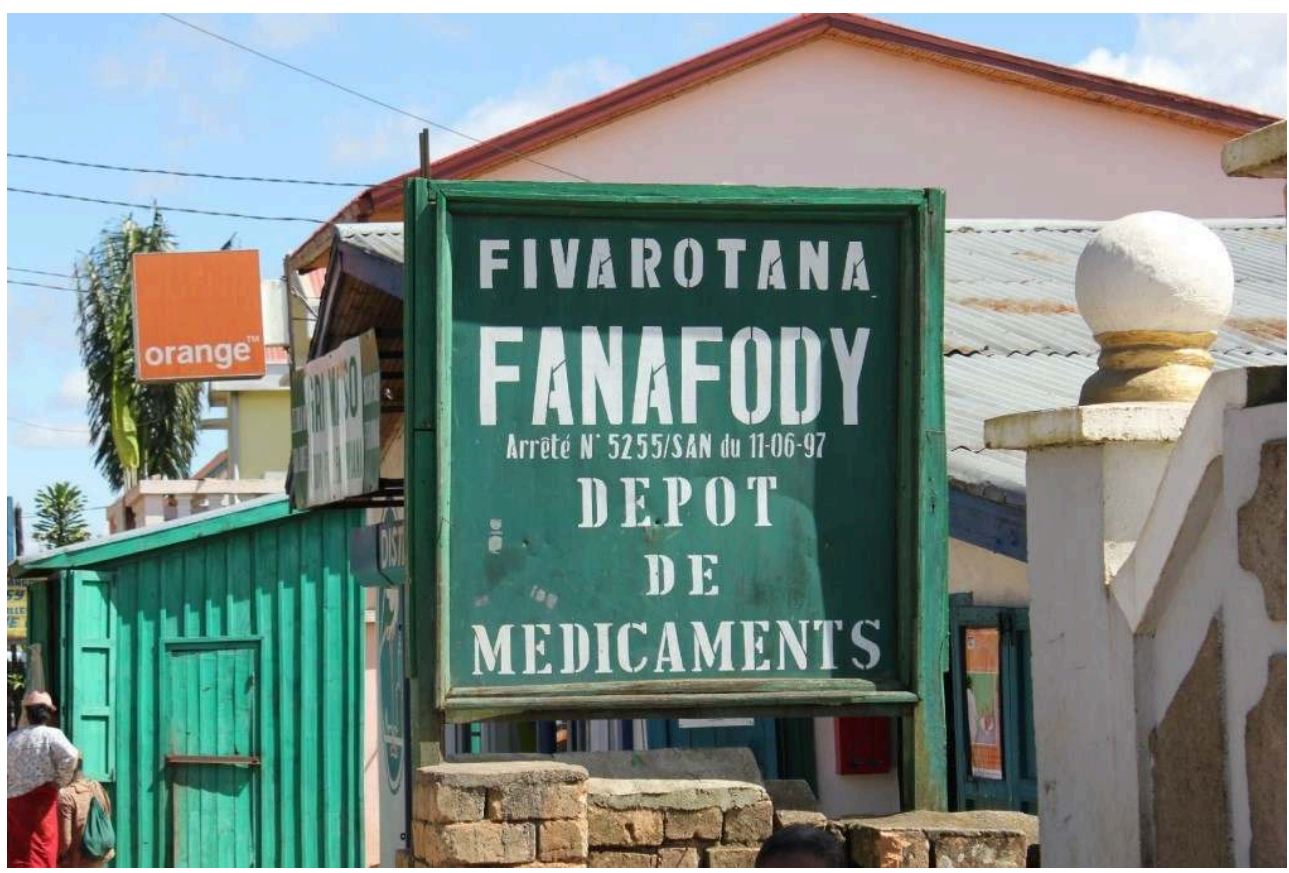

Source : Chiarella Mattern 
INDEX

Keywords: Anthropology, circulation, informal circuits, pharmaceutical system

\section{AUTHOR}

\section{CHIARELLA MATTERN}

Membre associée du CEPED (Institut de Recherche pour le Développement, Université de Paris, INSERM) et du LAAP (Laboratoire d'anthropologie prospective, Université Catholique de Louvain Belgique), chercheure responsable du service Santé \& Sciences Sociales, Unité Épidémiologie et de Recherche Clinique, Institut Pasteur de Madagascar, Antananarivo, Madagascar 